\title{
Hverken lighed eller anerkendelse? \\ Kvinder, mænd og skattelovgivning i Danmark
}

Af Anna-Birte Ravn

\section{Bragte kvindeorganisationernes} argumenter for lighed mellem agtefeller dem $i$ et dilemma, i forbold til dansk skattelovgivning 1903-1983, mellem økonomisk omfordeling til fordel for gifte udearbejdende kvinder og kulturel anerkendelse af kvinders arbejde $i$ hjemmet?
I

analysen fra 2001 af den danske velfærdsstat og Socialdemokratiet i det 20. århundrede konkluderer Niels Finn Christiansen og Klaus Petersen, at det lykkedes socialdemokraterne ikke kun at forlige klasseinteresser, men i sidste ende også at integrere kvinder $\mathrm{i}$ det fælles velfærdsstatsprojekt (Christiansen \& Petersen 2001, 181-82). At det skete 'i sidste ende' er formodentlig ikke uvæsentligt. Gennem størstedelen af den periode, de to forfattere betegner som den danske velfærdsstats "guldalder", årene fra 1950 til 1973, var gifte kvinder, hvad angår borgernes økonomiske pligter, kun en del af projektet i kraft af deres ægtemænd. Sambeskatning af ægtefæller betød, at gifte kvinder indtil 1970 ikke havde ret til at betale deres egen skat. Udfyldelsen af selvangivelsen var en årlig "performance", ${ }^{1}$ der mindede kvinderne om, at de ikke var fuldgyldige medborgere i det danske samfund.

Også Walter Korpi hæfter sig ved den danske velfærdsstats evne til at forlige såvel 
klasse- som kønsinteresser. I bogen Velfordsstat og socialt medborgerskab om den danske udvikling i komparativt perspektiv i perioden 1930 til 1995 hævder han, at både klasse- og kønsuligheden mindskedes i Danmark indtil ca. 1975. I perioden derefter fortsatte tendensen mod større kønsmæssig lighed, mens uligheden mellem klasser blev større (Korpi 2002). Problemet $i$ hans analyse er, at $k ø n$ og klasse betragtes som to adskilte kategorier uden indbyrdes sammenhæng. Ved at måle klasseulighed på husstandsindkomster ser han bort fra økonomiske uligheder inden for husstanden, mellem xgtefællerne, ligesom kønsarbejdsdeling ikke indgår i hans parametre. Kønsuligheden måles især på arbejdsmarkedsdeltagelse, som uden videre sættes lig med handlemuligheder. Det stemmer dårligt med en undersøgelse fra 2002, som viser, at en stor del af de ufaglærte kvinder $\mathrm{i}$ Kvindeligt Arbejderforbund (KAD) ikke har ressourcer og selvværd til at gøre op med "generationers overleverede kvindeforagt og selvfornedrelse" (Knudsen 2003). De nedvurderes både som klasse og som køn, og de identificerer sig med deres nedvurderede position, gør ikke oprør mod den, men betragter den tværtimod som en naturlig orden i verden. Køns- og klassepositionen virker indbyrdes forstærkende på nogle kvinders manglende handlemuligheder i dagens Danmark.

Ligesom KAD's formand, Lillian Knudsen, i citatet ovenfor, antager jeg, at nutidens uligheder mellem køn, som de kommer til udtryk materielt i kønsarbejdsdelingen og kulturelt i manglende anerkendelse af kvinders arbejde og kompetencer, både på arbejdsmarkedet og i familien, har nogle historiske rødder, som ikke er blevet rykket op og som stadig sender nye spirer op til overfladen i dag.

I det følgende diskuteres lighed mellem xgtefæller og anerkendelse af gifte kvinder som økonomiske medborgere på baggrund af politiske debatter om reformer af skattelovgivningen efter 1945, med hovedvægt på den moderne velfærdsstats formative år i 1950'erne og 1960'erne. Debatterne afslører en markant politisk modvilje mod at gennemføre fuld lighed i ægteskabet også inden for Socialdemokratiet og LO. Det heteroseksuelle ægteskab med manden som forsørger og kvinden som husmor var den dominerende norm, og bestræbelser på at udjæxne klasseforskelle forstærkede modviljen. I debatterne konstrueredes lighed mellem klasser og køn som antagonismer, og klasseforskelle præsenteredes som spørgsmål om social ulighed, mens kønsforskelle sås som et problem, der udelukkende handlede om manglende anerkendelse, om formelle rettigheder, ikke om social ulighed. For kvindeorganisationerne, som i begyndelsen af 1960'erne på tværs af klasser insisterede på social lighed mellem ægtefæller, opstod et uløseligt dilemma i forhold til anerkendelse af kvinders arbejde i hjemmet et dilemma, som stadig ikke er løst.

Nancy Frasers argumentation for en todimensional forståelse af retfærdighed som et spørgsmål om både kulturel anerkendelse og økonomisk omfordeling og for, at der i et kapitalistisk samfund er en sammenhæng mellem dem, er velegnet til at fange nuancerne i den politiske debat om gifte kvinders ret til at betale skat. En hovedpointe hos Fraser er, at der for bestemte grupper i bestemte kontekster kan være et dilemma mellem at argumentere for henholdsvis økonomisk omfordeling og kulturel anerkendelse, og at dilemmaet er større i forhold til køn end i forhold til klasse (Fraser 1997).

I Frasers analyse opstilles økonomisk omfordeling ("redistribution") og kulturel anerkendelse ("recognition") som idealtyper. I denne optik har kampen for omfordeling mellem klasser som politisk endemål at afskaffe klassesamfundet og klasser i det hele taget, og kulturel anerkendelse bliver derfor irrelevant; dilemmaet opstår ikke. Kampen for omfordeling mellem køn har som endemål at afskaffe kønnets betydning som økonomisk struktureringsfaktor; arbejdsdelingen mellem kvinder og mænd bå- 
de $\mathrm{i}$ forhold til lønnet og ulønnet arbejde og på arbejdsmarkedet skal nedbrydes. Men formålet er ikke at afskaffe køn i det hele taget. Derfor vil der samtidig være brug for en anerkendelsespolitik, et opgør med androcentrismen eller det forhold, at maskulinitet vurderes højere end feminitet. I bestemte kontekster kan der opstå, hvad Fraser kalder et "redistribution-recognition dilemma", som vel at mærke er et reelt dilemma: Dilemmaet består i, at anerkendelsespolitik tendentielt skaber fællesskab mellem kvinder, mens omfordelingspolitik tendentielt nedbryder dette fællesskab. Det er vanskeligt at forfølge begge mål, økonomisk omfordeling og kulturel anerkendelse, på samme tid. Vanskeligheden - og dilemmaerne - bliver ikke mindre af, at kvinder også har interesser og identiteter knyttet til klasse.

Fraser argumenterer for, at en transformativ politik, der har til hensigt at nedbryde kønsarbejdsdelingen (socialistisk feminisme) og destabilisere kønsdikotomier (feministisk dekonstruktion) har bedre muligheder for at overkomme dilemmaet end en affirmativ politik, der blot har til hensigt at sikre kvinders andel af jobs og uddannelser (liberal feminisme) og at opvurdere kvindeligheden (kulturel feminisme). Problemet med den transformative politik kunne dog ifølge Fraser være, at både en dekonstruktiv-feministisk kulturel strategi og en socialistisk-feministisk økonomisk politik "are far removed from the immediate interests and identities of most women, as they are currently culturally constructed" (Fraser 1997, 30).

Inden analysen af de politiske debatter om reformer af skattelovgivningen efter 1945 presenteres nedenfor kort de hovedtræk i den danske skattelovgivning fra 1903 til 1983, som debatterne handlede om. Selve analysens hovedaktører er repræsentanter for kvindeorganisationerne: Dansk Kvindesamfund (Danske Kvinders Nationalråd) og kvinder organiseret i Socialdemokratiet og LO, som i og uden for de formelle parlamentariske institutioner søgte at præge den offentlige debat og at påvirke lovgivningsprocessen i retning af større socioøkonomisk lighed mellem xgtefæller og kulturel anerkendelse af gifte kvinder som fuldgyldige medborgere.

\section{DANSK SKATTELOVGIVNING 1903-83}

Dansk skattelovgivning siden den første indkomst- og formueskattelov i 1903 og indtil loven om skattemæssig ligestilling af xgtefæller med virkning fra 1983 var både socioøkonomisk og kulturelt uretfærdig over for gifte kvinder. Den var et klart udtryk for ulighed mellem xgtefæller, både hvad angår økonomisk omfordeling og kulturel anerkendelse, og de to typer af uretfærdigheder forstærkede gensidigt hinanden.

Umiddelbart var lovgivningen udtryk for manglende kulturel anerkendelse af gifte kvinder som personer og medborgere i det danske samfund. 1903-lovens formulering: "Familieoverhovedet beskattes af hele Husstandens Indkomst. Til Husstanden henregnes den med Manden samlevende Hustru, selv om hun har Særformue ..." (Lov af 15. Maj 1903) blev ganske vist ændret med kildeskattelovens ikrafttræeden fra 1970, men kun på den måde, at begrebet "familieoverhoved" blev erstattet af udtrykket "hovedperson". I lovgivningen om kommunale skatter var hustruen ikke engang nævnt; det blev taget som en selvfølge, at lovens skattesubjekt "enhver" ikke omfattede gifte kvinder (Pedersen 1966, 14). Skatteborgeren var en mand, og den kvinde, der giftede sig, blev i skattelovgivningen et vedhæng til manden, en ikke-person.

Men i sine konsekvenser bidrog skattelovgivningen også til at forstærke den økonomiske ulighed mellem ægtefællerne - og til at modvirke gifte kvinders incitament til lønnet beskæftigelse uden for familien. At familien betragtedes som en enhed med manden som overhoved betød nemlig, at gifte kvinder blev beskattet hårdere end gifte mænd. Gifte kvinder havde siden 1880 
haft ret til selv at disponere over deres egen indtjening (Blom \& Tranberg 1985, 37), men sambeskatningen betød, at kvindens indtrgt blev lagt oven i mandens, og i det progressive skattesystem var konsekvensen, at kvinderne kom til at betale mere i skat end deres mænd. Desuden var det manden, der fik fradragene - med samme konsekvens. Det var xgtemanden, der fik det skattefri bundfradrag, og 1903-loven gav ham også fradrag for børn. Med revisionen af loven i 1912 (Lov af 8. Juni 1912) fik manden desuden et såkaldt "hustrufradrag", hvis formål var at kompensere for det husarbejde, kvinden ikke kunne udføre, hvis hun havde beskæftigelse uden for hjemmet. Hustrufradraget kan læses som et udtryk for kulturel anerkendelse af husarbejdet, men der var ikke tale om nogen "husmorløn" - det blev kun givet, når husmoderen på grund af udearbejde ikke kunne udføre arbejdet - eller økonomisk omfordeling til fordel for de gifte kvinder, der havde udearbejde, tværtimod. Fradraget blev givet til manden. Endelig indførtes ved xndring af loven i 1922 (Lov af 10. April 1922 ) som noget nyt et forsørgerfradrag, 2 det vil sige et fradrag til manden for at forsørge hustruen. Den opfattelse, at manden er familiens forsørger, er med andre ord ikke udtryk for en såkaldt 'traditionel' tankegang, men et produkt af det danske samfunds modernisering i det tidlige 20. århundrede, ${ }^{3}$ og dens inkludering i skattelovgivningen $i$ form af fradrag til æegtemanden betød, at de økonomiske uligheder mellem kvinder og mænd i familien blev forstærket.

Derimod er det vanskeligt at give en entydig karakteristik af forsørgerfradraget i forhold til kulturel anerkendelse af kvinders arbejde i familien. Det kan ses som udtryk for usynliggørelse og altså manglende kulturel værdsættelse af dette arbejde. Men det kan også tolkes som et udtryk for det modsatte, og det ville give mening ved sammenligning med den samtidige modernisering af ægteskabslovgivningen. Ægteskabsloven af 1925 fastslog ægtefællernes gensidige forsørgerpligt og gav for første gang den gifte kvinde ansvaret for at bidrage til familiens forsørgelse på linje med manden. Dette ansvar kunne for hustruens vedkommende opfyldes gennem arbejde i hjemmet, ${ }^{4}$ og dermed fik gifte kvinder formel lighed og kulturel anerkendelse som forsørgere netop i kraft af deres arbejde i familien. Skattelovgivningens forsørgerfradrag kan ses som en indirekte anerkendelse af gifte kvinders arbejde i familien som vigtigt for samfundet.

Med kildeskatteloven fra 1970 (Lov af 31. marts 1967) indførtes særbeskatning af xgtefæller, 5 men kun af visse indkomster. Fradraget for børn blev omlagt til børnetilskud, der udbetaltes til moderen, og blev inkluderet i sociallovgivningen. ${ }^{6}$ Disse to ændringer bidrog både til kulturel anerkendelse af gifte kvinders arbejde i og uden for familien og til en mere retfærdig økonomisk fordeling mellem xgtefællerne. Hustrufradraget blev i første omgang afskaffet, så igen indført for de laveste indtxgter, men endeligt afskaffet fra 1975 (Ligestillingsrådet 1978, 19). Og forsørgerfradraget blev ophævet, men indført i ny form ved, at det gifte par fik to personfradrag, uanset om kun den ene ægtefælle havde erhvervsmæssig beskæftigelse. I de tilfælde, hvor den gifte kvinde var hjemmearbejdende, fik $\mathfrak{x g}$ temanden således et dobbelt personfradrag.

Lov om skattemæssig ligestilling af ægtefæller (Lov af 26. maj 1982), der trådte i kraft fra 1983, betød først og fremmest, at xgtemanden ikke længere betragtedes som skattemæssig hovedperson. Der blev nu skelnet mellem “ægtefælle I og II”, og ægtefælle I, som var den med den største arbejdsindkomst, kunne i princippet være kvinden. Den gifte kvinde blev med andre ord kulturelt anerkendt som en selvstændig skatteretlig person. Men xgteparret blev fortsat sambeskattet af formueindkomster, og deres samlede beskatning blev ikke ændret i forhold til reglerne siden 1970. Eftersom ægtefælle I i langt de fleste tilfælde var manden, og kvindens formueskat blev beregnet på ‘toppen' af mandens skattepligti- 
ge indkomst, ændrede 1982-loven ikke ved den økonomiske omfordeling i familien (Bergenfeldt 1982, 53f).

Det hører også med til historien, at gifte kvinders manglende ret til at betale skat kunne få alvorlige konsekvenser for deres politiske medborgerskab. Indtil 1966 var gifte kvinders ret til at deltage i kommunalvalg og blive valgt til kommunalbestyrelser afhængig af, at deres mænd havde betalt skat (Pedersen 1966, 15f).

Den danske skattelovgivning i perioden 1903-70(83) bidrog gennem sine kulturelle og økonomiske betydninger til at skabe en ny kønsorden, hvor den heteroseksuelle kernefamilie med manden som forsørger og kvinden som husmor blev den ideologiske norm og i høj grad realiseret i praksis også inden for den bedrestillede del af arbejderklassen. Både økonomisk og kulturelt favoriserede skattelovgivningen kernefamilien på andre familieformers bekostning. Den favoriserede gifte mænd økonomisk på alle andre skatteborgeres bekostning - enlige forsørgere (kvinder og mænd) med erhvervsarbejde fik f.eks. ikke noget "hustrufradrag" som kompensation for det husarbejde, de ikke kunne udføre - og skabte økonomiske interesser for (gifte) mænd $\mathrm{i}$ at styrke og bevare kernefamilien. Den bidrog til at forstærke de økonomiske uligheder mellem ægtefællerne og var udtryk for manglende kulturel anerkendelse af gifte kvinder som medborgere i det danske samfund. Lovgivningen indeholdt imidlertid også elementer af kulturel anerkendelse af gifte kvinders arbejde i hjemmet, som kunne medvirke til at farve kvinders identiteter og interesser. Den indebar med andre ord et potentielt dilemma for kvinder mellem økonomisk omfordeling mellem kønnene og kulturel anerkendelse af kvinders aktiviteter som husmødre.

Både i Dansk Kvindesamfund og blandt socialdemokratiske kvinder blev dette dilemma meget håndgribeligt $\mathrm{i}$ begyndelsen af 1950'erne, hvor kernefamilien med manden som forsørger og kvinden som husmor var blevet den både kulturelt og økonomisk dominerende familieform i Danmark.

\section{DANSK KVINDESAMFUndS TIDLIGE PROTEST}

Dansk Kvindesamfund havde siden 1913 protesteret mod kønsulighederne i skattelovgivningen. Foreningens hovedsynspunkt var, at staten gennem skatteregler, sociallovgivning m.v. skulle påtage sig et økonomisk ansvar for forsørgelse af børn, mens forsørgelse af voksne personer, kvinder som mænd, i udgangspunktet var den enkeltes eget ansvar. Skattelovgivningen skulle ikke begunstige den gifte mand. Kravet var særbeskatning af ægtefæller og afskaffelse af særfradrag for ægtemanden (Ravn 2000a). Som nævnt fik denne protest ingen konsekvenser - tværtimod blev kønsskævheden styrket med indførelsen af forsørgerbegrebet i skatteloven af 1922. Og foreningen fik intet ud af utallige henvendelser til regering og rigsdag i mellemkrigstiden. Den blev heller ikke taget alvorligt, da den i forbindelse med nedsxttelse af en skattelovskommission i 1937 henvendte sig for at blive repræsenteret. Kommissionen kom til at bestå af 29 mænd, repræsentanter for alle politiske partier og for embedsværket, men ingen kvinder.

Dansk Kvindesamfunds tidlige protest mod skattelovgivningen fokuserede primært på gifte kvinders rettigheder. Det var irrationelt og ydmygende for voksne kvinder, som før ægteskabet var blevet betragtet som fuldgyldige medborgere, at de som følge af indgåelse af rgteskab blev behandlet som umyndige børn, og det var en oplagt uretfærdighed, at en gift kvinde kunne miste sin kommunale stemmeret og få tilbageholdt eventuel indkomst eller gjort udlæg i sin formue i tilfælde af, at xgtemanden ikke havde betalt skatten. Skattelovgivningen var en trussel mod selve xgteskabet som institution, hævdede foreningen. Om forsørgerfradraget mente Dansk Kvindesamfund, at det var en fornærmelse mod 


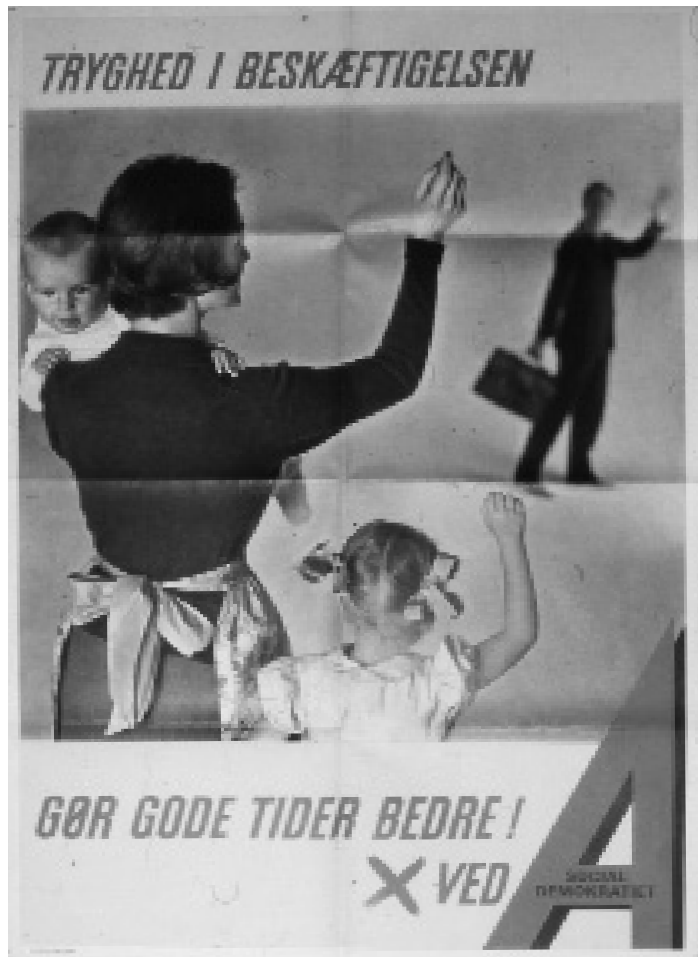

Valgplakat for Socialdemokratiet, 1960

hustruen at betragte manden som familiens forsørger. Det var et udtryk for manglende værdsættelse af gifte kvinders arbejde i familien, men det var også fordelingspolitisk urimeligt: Der var ikke nogen grund til at give en mand skattefradrag, fordi han giftede sig og således fik det arbejde, han tidligere havde måttet betale for, gjort gratis (Ravn 2000a).

Kravene om særbeskatning og afskaffelse af især forsørgerfradraget indebar en økonomisk omfordeling mellem ægtefællerne, men kun i de tilfælde, hvor hustruen havde lønnet arbejde uden for hjemmet. Dansk Kvindesamfund forholdt sig ikke officielt til skattelovgivningens økonomiske konsekvenser for de kvinder, der var husmødre, og som derfor ikke havde en egen indkomst, som de kunne blive beskattet af. Interne debatter i foreningen tyder på, at man forventede, at revisionen af rgteskabsloven ville løse dette problem ved at give den hjemmearbejdende gifte kvinde ret til en del af mandens indkomst. Dilemmaet var således erkendt, men forventedes løst.

\section{SKATTELOVSKOMMISSIONEN AF 1937}

Skattelovskommissionens betænkninger udkom i 1948 og 1950. Kommissionen anbefalede at bibeholde sambeskatningen. Hovedargumentet var, at ægteskabslovens gensidige forsørgerpligt gjorde det gifte par - i modsætning til tilfældigt samlevende personer - til "et virkeligt økonomisk Fællesskab". Det eneste "mulige og naturlige" var derfor at underkaste alle xgtepar en ensartet skattemæssig behandling (det såkaldte “evneprincip"). Om indkomsten var tjent af begge xgtefæller eller af manden alene var en privat sag uden interesse for det offentlige. Principielt kunne gifte par sam- eller særbeskattes, men sambeskatning forekom kommissionen at være "den eneste teknisk fremkommelige Vej". Til trods for kvinders stadig større deltagelse i erhvervslivet mente kommissionen, at $\mathrm{i}$ et landbrugsland som Danmark ville familier, hvor hustruen var medhjælpende - og det var teknisk umuligt at opgøre hendes indkomst, og familier, hvor manden alene havde indkomst, "utvivlsomt" lang tid fremover udgøre den overvejende del af samtlige xgteskaber. Kommissionen gjorde således kernefamilien med manden som forsørger og kvinden som husmor eller medhjælpende hustru til normen også for fremtiden.

Sambeskatningen burde gennemføres konsekvent og ligestille alle xgtepar, mente kommissionen. Derfor foreslog den i 1948betænkningen at afskaffe det såkaldte "hustrufradrag”, der var indført i 1912 med henblik på at lette gifte kvinders erhvervsarbejde uden for hjemmet ved at kompensere manden for det husarbejde, hustruen ikke kunne udføre. Hovedsynspunktet i 1948 var, at kvinders arbejde i hjemmet principielt hørte til "Privatforbrugets Omraade" og altså ikke var en sag af interesse for det of- 
fentlige (Betænkning 1948). Husarbejdet blev således i denne betænkning genprivatiseret.

Hustrufradraget ville kunne begrundes, mente kommissionen, hvis hustruens arbejde i hjemmet betragtedes som værdiskabende, som en produktiv aktivitet, men det ville være meget vanskeligt at opgøre værdien af dette arbejde, fordi det ikke resulterede i en pengeindkomst. Der var meget store forskelle både på den tid, gifte kvinder anvendte på husarbejdet, og på deres interesse for og kvalifikationer som husmødre. Deres helbredstilstand kunne også spille ind. Men vigtigere for kommissionen var det nok, at en opretholdelse af hustrufradraget betød, at familier med samme økonomiske vilkår blev stillet ulige i beskatningen, fordi fradraget ikke blev givet til xgtepar, hvor hustruen faktisk udførte husarbejde eller var medhjælpende i mandens bedrift. Det var i øvrigt også uretfærdigt, at enlige kvinder med børn i modsætning til gifte kvinder uden børn ikke var omfattet af denne kompensation. Både af hensyn til ligestilling af familier (evneprincippet) og af tekniske grunde mente kommissionen derfor, at hustrufradraget skulle afskaffes (Betænkning 1948).

Forslaget om at afskaffe hustrufradraget ville indebære, at den tidligere kulturelle anerkendelse af (nogle) kvinders (manglende) arbejde i hjemmet ville bortfalde, og måske, at tilgangen af kvinder til arbejdsmarkedet ville blive mindre. Ændringen viste sig at være politisk uholdbar. I Skattelovskommissionens betænkning fra 1950 genindførtes hustrufradraget. Argumentet var her at undgå, at indgåelse af xgteskab skulle medføre højere beskatning, med andre ord at værne om xgteskabet som institution (Betænkning 1950). Den fortsatte kulturelle anerkendelse af husarbejdet i form af et hustrufradrag kan således tolkes som et forsøg på at undgå, hvad kommissionen uden tvivl betragtede som et større onde, nemlig en tendens til opløsning af den heteroseksuelle kernefamilie.

\section{OMKRING SKATTELOVSKOMMISSIONEN}

Mens Skattelovskommissionen stadig arbejdede, blev hustrufradraget, der ikke var blevet reguleret siden 1912, og hvis skattemæssige betydning var blevet kraftigt svækket, forhøjet med virkning fra skatteåret $1947 / 48$. Begrundelsen var manglen på arbejdskraft og ønsket om at fjerne de hindringer, sambeskatningen mentes at have på gifte kvinders tilgang til arbejdsmarkedet.

Men det var ikke tilstrækkeligt, mente Dansk Kvindesamfund. I 1945 havde foreningen udgivet pjecen Skat og Agteskab forfattet af Inga Dahlsgaard og Erik Ib Schmidt (Dahlsgaard \& Schmidt 1945). Begge var socialdemokrater, og Inga Dahlsgaard fulgte i 1947 pjecen op med en artikel af samme navn i det andet nummer af de socialdemokratiske kvindeudvalgs blad Frie Kvinder (Dahlsgaard 1947). Artiklen argumenterede for, at sambeskatningen var "urimelig" over for gifte kvinder og "uretfærdig" over for ægtepar, hvor begge havde erhverv. Urimeligheden gik på, at gifte kvinder i skattelovgivningen ikke var fuldgyldige medborgere eller med andre ord kulturelt anerkendte. Ifølge Dahlsgaard var det særlig urimeligt $\mathrm{i}$ forhold til hjemmearbejdende kvinder, der ikke havde mulighed for at råde bod på mandens eventuelle forsømmelighed med hensyn til at betale skatten.

Uretfærdigheden eller den økonomiske ulighed derimod handlede $\mathrm{i}$ hendes forståelse (ligesom senere i Skattelovskommissionens betænkninger) ikke om forholdet mellem køn, men om forholdet mellem familietyper og om skattesystemets begunstigelse af den mandlige forsørger/kvindelige husmor og/eller medhjælpende hustru-familie. Skattelovgivningen var umoderne; den tænkte den gifte kvinde som del af en forældet naturaløkonomi, der nu i høj grad var erstattet af en pengeøkonomi, mente Dahlsgaard. En hovedpointe i pjecen fra 1945, som Dahlsgaard også nævnte i 1947 artiklen, var, at i modsætning til gifte kvinders udeerhverv blev det husarbejde, hu- 
struerne udførte i familien, overhovedet ikke beskattet. Dahlsgaard tilføjede beroligende, at "intet fornuftigt Menneske" vel ville finde på at beskatte husmødrenes naturalindtægt; hensigten var alene at underbygge argumentet om, at toforsørgerfamilier blev behandlet økonomisk uretfærdigt. Dahlsgaards og Schmidts kulturelle anerkendelse af husmødrenes arbejde stod i direkte modstrid med den økonomiske omfordeling, de ønskede: fra den mandlige forsørger/kvindelige husmor-familie til toforsørgerfamilien.

Efter udgivelsen af Skattelovskommissionens betænkninger opgav både socialdemokratiske kvinder og Dansk Kvindesamfund for en tid kravet om særbeskatning. I Folketinget protesterede den radikale Kirsten Gloerfelt-Tarp forgæves mod, hvad hun opfattede som en useriøs og uretfærdig behandling af gifte kvinder. Og selv om den socialdemokratiske Edel Saunte, der kommenterede betænkningerne i Frie Kvinder i 1951, mente, at de gxldende skatteregler var økonomisk uretfærdige over for udeerhvervende gifte kvinder og ikke kun over for de familier, de indgik i, accepterede hun forhøjelsen af hustrufradraget som alternativ til særbeskatningen, forudsat at gifte kvinder fik deres eget skatteskema og egen skattebillet, at de med andre ord blev kulturelt anerkendte. Baggrunden for Sauntes accept af den gældende skattelovgivning var økonomiske beregninger i Københavns Kommune, der viste, at efter forhøjelsen af hustrufradraget ville de gældende regler være en fordel for $85 \%$ af alle toforsørgerfamilier, mere prxcist dem med de laveste indtxgter (Saunte 1951). Økonomisk omfordeling mellem køn måtte med andre ord vige for større lighed mellem familier i forskellige klasser.

I Dansk Kvindesamfund havde Inga Dahlsgaards og Erik Ib Schmidts pjece fra 1945 vakt stor modstand på grund af den blotte tanke om at beskatte husmødrenes arbejde, og i begyndelsen af 1950'erne opgav foreningen - ligesom og af samme grund som Edel Saunte - særbeskatningen til fordel for en forhøjelse af hustrufradraget. Selv om de mente, at det var uretfærdigt, valgte socialdemokratiske kvinder og Dansk Kvindesamfund i begyndelsen af 1950'erne at opgive den økonomiske omfordeling mellem køn til fordel for større lighed mellem klasser. De undgik dermed dilemmaet mellem kulturel anerkendelse af kvindearbejdet i hjemmet og økonomisk omfordeling mellem køn, og Edel Saunte kunne med fuld styrke karakterisere tankerne om at afskaffe hustrufradraget som et vidnesbyrd om "mændenes sædvanlige foragt og manglende forståelse for, hvad en husmoder i virkeligheden betyder for et hjems økonomi” (Saunte 1951, 3).

Men dilemmaet blev aktualiseret igen i begyndelsen af 1960'erne, hvor nye repræsentanter for arbejderbevægelsen og Dansk Kvindesamfund insisterede på økonomisk retfærdighed for de udearbejdende gifte kvinder.

\section{FINANSMINISTERENS UDVALG - OG DEREFTER}

I 1961 blev kvinder for første gang taget med på råd i skattespørgsmål. Danske Kvinders Nationalråd blev anmodet om at udpege to repræsentanter til finansministerens Udvalg om Ægtefællers Beskatning, og organisationen udpegede dels Jytte Christensen, der var ansat i statens ligningsdirektorat og formand for Dansk Kvindesamfunds skatteudvalg, dels Ester Frandsen som repræsentant for husmødrene. Men også LO udpegede en kvinde som den ene af sine to representanter i udvalget: Ella Olsen, der på det tidspunkt var sekretær i Tobaksarbejderforbundet. ${ }^{7}$ Udvalget, der kom til at bestå af 6 mænd og 3 kvinder, afgav betænkning i 1963.

Betænkningen afspejlede en markant uenighed; den indeholdt tre mindretalsindstillinger, men kvindernes fingeraftryk var tydelige, også i udvalgets frelles vurderinger af konsekvenserne af den gxldende skatte- 
lovgivning. I modsætning til Skattelovskommissionen af 1937 omfattede udvalgets vurderinger ikke kun fordelingspolitiske hensyn til familier som helhed (evneprincippet), men også hensynet til gifte kvinder som selvstændige individer (individualprincippet). Udvalget konkluderede, at den økonomiske virkning af sambeskatningen kombineret med den progressive beskatning $\mathrm{i}$ mange tilfælde var en forøgelse af skattebyrden, når to enlige indgik xgteskab. Denne forøgelse blev begrænset af hustrufradraget, men der var ingen tvivl om, at en kvindes indtægt ved giftermål blev meget hårdere beskattet (Betænkning 1963, 5760). Ægteskab indebar med andre ord en kraftig økonomisk omfordeling fra kvinden til manden. De sociale virkninger af de gxldende skatteregler var formodentlig en begrænsning af gifte kvinders arbejdsindsats uden for hjemmet, mente udvalget. I alle tilfælde gjorde disse regler indhug i kvindernes frihed til selv at bestemme, om de ville arbejde ulønnet i eget hjem eller lønnet uden for hjemmet (ibid, 60-63). Endelig fastslog betænkningen om de retlige virkninger, at uanset om sambeskatningen bevaredes, eller der indførtes særbeskatning, var den manglende anerkendelse af gifte kvinder som skatteretlige personer uholdbar (ibid, 63-64). ${ }^{8}$

Ella Olsen og Jytte Christensen gik i mindretal på en indstilling, der foreslog særbeskatning af æegtefæller, ophævelse af forsørgerskala og af hustrufradrag. ${ }^{9}$ Deres hovedargument var "princippet om kønnenes ligeberettigelse". Sambeskatningen var et levn fra fortiden og tvang "mere eller mindre" den gifte kvinde "tilbage til husmodergerningen", mente de. Den var diskriminerende over for gifte kvinder, der efter Ella Olsens og Jytte Christensens opfattelse selv måtte beslutte, om de ønskede at lægge deres arbejdskraft i hjemmet, hvor den var af "overordentlig betydning for $x g$ tefællernes økonomi”, eller på arbejdsmarkedet. Beskatningen burde være uafhængig af ægteskabelig stilling; det var "en men- neskerettighed", mente de, og en forhøjelse af hustrufradraget, som foreslået af et andet mindretal i udvalget, ville hverken økonomisk eller psykologisk (læs: kulturelt) tilgodese målsætningen om kønnenes ligeberettigelse. En sådan forhøjelse ville i øvrigt også være uretfærdig over for medhjælpende hustruer og enlige med selverhverv. De sluttede argumentationen med at fremhæve, at særbeskatning ville være den teknisk set mest enkle løsning, især under en kildeskatteordning (ibid, 72-73 og 84-87).

\section{DilemMAET}

Ella Olsens og Jytte Christensens forslag indebar kulturel anerkendelse af alle gifte kvinder som fuldgyldige skatteborgere - i princippet også i de tilfælde, hvor kvinden var husmor. Men kun i familier hvor begge xgtefæller havde en pengeindkomst, ville der ske en økonomisk omfordeling fra manden til kvinden. I en debat i Frie Kvinder med den socialdemokratiske finansminister, Poul Hansen, understregede de, at denne familietype især forekom blandt arbejdere, funktionærer og mindre tjenestemænd (Jensen \& Christensen 1964, 1920). Men ligesom for Inga Dahlsgaard var deres dilemma i forhold til husmødrene tydeligt. På den ene side blev husmødrenes økonomiske indsats fremhævet; på den anden side blev de skildret som et levn fra fortiden, og det har formodentlig været en ringe trøst, at Ella Olsen og Jytte Christensen præciserede, at husmødrene efter deres forslag skulle betale $0 \mathrm{kr}$. i skat - det økonomisk betydningsfulde arbejde i hjemmet skulle altså ikke beskattes. Derimod mente de to forslagsstillere, at medhjælpende hustruers indsats i modsætning til tidligere skulle anerkendes skattemæssigt - dog ikke gennem et hustrufradrag, der var begrundet $\mathrm{i}$ deres manglende arbejde i hjemmet, men gennem et dobbelt bundfradrag, der var erhvervsmæssigt betinget og tilfaldt alle personer med en pengeindkomst. Hustrufradraget skulle som nævnt efter forslaget 
helt bortfalde (Betænkning 1963, 84-87). Dermed bortfaldt også den indirekte kulturelle anerkendelse af gifte kvinders husarbejde, som dette fradrag var et udtryk for.

Ella Olsen og Jytte Christensen argumenterede for, at gifte kvinder i forhold til skattelovgivningen skulle være individer $\mathrm{i}$ deres egen ret og kulturelt anerkendes som sådanne (individualprincippet), men konsekvenserne af deres forslag ville ikke kun være en økonomisk omfordeling fra gifte mænd til (nogle) kvinder, men også fra den mandlige forsørger/kvindelige husmor-familie til toforsørger- eller dobbeltindkomstfamilien. I diskussionen med finansminister Poul Hansen gik Ella Olsen til direkte angreb på, hvad hun opfattede som et forældet forsørgerbegreb og dets favorisering af gifte mænd på andre skatteyderes bekostning (Olsen 1963, 70-71). Men konsekvensen af at afskaffe forsørgerskalaen ville også være, at den indirekte kulturelle anerkendelse af husarbejdet helt ville forsvinde - og at husmorfamilier ville få færre penge til rådighed.

Den bastante modstand mod Ella Olsens og Jytte Christensens mindretalsindstilling var begrundet i økonomisk retfærdighed i forhold til familietyper og klasser. Økonomisk omfordeling mellem køn indgik ikke i modstandernes opfattelse af en retfærdig skattelovgivning. I udvalget foreslog et mindretal på tre medlemmer inklusive formanden at bevare sambeskatningen, men at tage hensyn til behovet for gifte kvinders arbejdskraft ved at forhøje hustrufradraget. Selv om forsvaret for den mandlige forsørger/kvindelige husmor-familie var noget nedtonet, var argumenterne grundlæggende de samme som i Skattelovskommissionens betænkninger: Sambeskatningssystemet var mest retfærdigt over for og kunne omfatte alle ægtepar (evneprincippet). Særbeskatning kunne ikke teknisk lade sig gøre i de tilfælde, hvor hustruen var medhjælpende, og den ville favorisere xgtepar, hvor begge havde store indtxgter, helt uforholdsmæssigt, mente dette mindretal (Be- tænkning 1963, 71-72). Ægteparret opfattedes i deres forslag stadig som en "naturlig" økonomisk enhed.

De sidste fire medlemmer af udvalget, inklusive Danske Kvinders Nationalråds repræsentant for husmødrene, Ester Frandsen, tog ikke stilling til forslagene om henholdsvis særbeskatning og forhøjelse af hustrufradraget. De mente, at en stillingtagen måtte bero "på almindelige værdinormer og på politiske vurderinger" (ibid. 73). Af indlæg på et møde arrangeret af $\mathrm{DKN}$ efter offentliggørelse af udvalgsbetænkningen fremgik det, at Ester Frandsen principielt støttede særbeskatning, men mente, at den konkrete udformning af forslaget var problematisk i forhold til de familier, hvor hustruen var husmor. For professor, dr.jur. Bent Christensen var klasseinteresser afgørende; han formulerede på samme møde et dilemma mellem kulturel anerkendelse af gifte kvinder og social omfordeling mellem klasser. Og han blev støttet af Svend Bache Vognbjerg, der ligesom Ella Olsen var udpeget af LO. Vognbjerg tog som sagt ikke stilling i udvalget, men til LO's forretningsudvalg indstillede han, at Landsorganisationens reaktion på udvalgsbetænkningen skulle være at foreslå bevarelse af sambeskatningen og forhøjelse af hustrufradraget. Selv om han principielt gik ind for særbeskatning af ægtefæller - og selv om særbeskatning indgik som et krav i Socialdemokratiets program, kunne han ikke støtte Ella Olsens og Jytte Christensens forslag, fordi det efter hans mening ville give uforholdsmæssigt store skattelettelser til ægtepar, hvor begge arbejdede, mens "skatteborgere, hvor konen ikke har udearbejde", ville komme til at betale mere selv "ved ganske jævne indtægter" (Vognbjerg 1963, 2). I hans argumentation lå således både fordelingspolitiske hensyn i forhold til klasse, og hvad han selv kaldte "familie-politiske hensyn" (Vognbjerg 1963, 3), nemlig specielt hensynet til den mandlige forsørger/kvindelige husmor-familie, som sandsynligvis ville komme til at betale mere i skat ved 
særbeskatning. I modsætning til Ella Olsen og Jytte Christensen mente Vognbjerg, at de uheldige økonomiske virkninger af sambeskatningen, i hvert fald for størstedelen af fagbevægelsens medlemmer, ville blive ophævet med forhøjelsen af hustrufradraget. I hans optik var retfærdighed og økonomisk omfordeling således udelukkende knyttet til klasse og til familien som en økonomisk enhed. Ligesom Bent Christensen - og den socialdemokratiske finansminister Poul Hansen (Hansen 1963, 83-84) - betragtede han kønsproblemet i beskatningen som alene et spørgsmål om kulturel anerkendelse, et spørgsmål om "følelser" og dermed af mindre betydning, ikke om økonomisk omfordeling.

\section{KonkLusion}

Den danske skattelovgivning, som den blev udformet i begyndelsen af det 20. århundrede, i årene fra 1903 til 1922, var først og fremmest udtryk for en bestemt familienorm, den heteroseksuelle kernefamilie med manden som forsørger og kvinden som husmor. Det var denne familietype, som begunstigedes kulturelt og økonomisk gennem mandens status som familiens overhoved, gennem sambeskatning, der modvirkede gifte kvinders tilgang til arbejdsmarkedet, og ved, at alle fradrag børne-, hustru- og forsørgerfradrag - tilfaldt manden.

Gifte kvinder var i denne lovgivning ikke kun kulturelt nedvurderet, de var ikke-personer, og hvis de bidrog til familiens forsørgelse gennem arbejde for andre, fik de på grund af skattereglerne forholdsvis mindre tilbage af deres indkomst end deres xgtemænd. Reglerne indebar en økonomisk omfordeling fra gifte kvinder til gifte mænd. Hensigten med hustrufradraget var at bøde på de uheldige virkninger af sambeskatningen ved at gøre hustruens arbejde uden for hjemmet mere attraktivt. Det indebar også en indirekte anerkendelse af værdien af kvindearbejdet i hjemmet, men det tilfaldt manden og bidrog således yderligere til den økonomiske ulighed mellem xgtefællerne. Forsørgerfradraget kan tolkes som manglende kulturel anerkendelse af kvindearbejdet i familien eller det modsatte, men i og med at den mandlige forsørger/ kvindelige husmor-familie vandt frem, blev det af økonomisk betydning for stadig flere familier, også for husmødrene.

I de politiske debatter om ændringer af skattelovgivningen i perioden efter 2 . Verdenskrig ses en klar kønskonflikt, men den blev ikke opfattet sådan af alle deltagere $\mathrm{i}$ debatten. De fleste mandlige debattører og beslutningstagere forsvarede den eksisterende lovgivning og dermed den heteroseksuelle kernefamilie i form af en mandlig forsørger/kvindelig husmor- eller medhjælpende hustru-familie. Presset af et $ø$ get behov for kvindelig arbejdskraft accepterede de nødtvungent en forhøjelse af hustrufradraget som det mindste onde sammenlignet med særbeskatning. For dem handlede det fordelingspolitiske dels om lighed mellem forskellige (kerne)familietyper, dels om lighed mellem klasser. De var ikke fanget i noget dilemma i forhold til køn, fordi de grundlæggende ikke mente, at skattelovgivningen udgjorde et kønsproblem. Hvis den gjorde, handlede det udelukkende om formelle rettigheder eller kulturel anerkendelse - underforstået et problem af mindre betydning. Især de socialdemokratiske mænd konstruerede et dilemma mellem køn og klasse i forhold til økonomisk omfordeling. Det var ikke muligt gennem skattelovgivningen at opnå større økonomisk lighed mellem både klasser og køn, hævdede de. En opfyldelse af kravet om særbeskatning m.v. ville kun komme velstillede ægtepar med to indkomster til gode, mente de, og under de vilkår var deres eget svar givet: Lighed mellem køn måtte vige for lighed mellem klasser.

For de kvindelige debattører, der argumenterede imod den gxldende skattelovgivning og for skattemæssig lighed mellem xgtefæller, opstod derimod flere dilemma- 
er. For det første dilemmaet mellem kulturel anerkendelse af kvindearbejdet i hjemmet og økonomisk omfordeling mellem kvinder og mænd. En kulturel værdsættelse af husarbejdet (hustrufradrag) kunne potentielt skabe fællesskab mellem kvinder uanset familietype (og klasse), mens en økonomisk omfordeling mellem kvinder og mænd (særbeskatning m.v.) ville skabe økonomiske modsætninger mellem kvinder i forskellige familietyper. For det andet dilemmaet mellem økonomisk omfordeling i forhold til køn eller klasse. Særbeskatning af xgtefæller indebar en økonomisk omfordeling til fordel for kvinder med erhvervsarbejde, men fordelen for familier i forskellige klasser var afhængig af de aktuelle skattesatser. $\mathrm{Og}$ arbejderklassefamilier, for hvem den mandlige forsørger/kvindelige husmorfamilie var blevet en realitet, ville $i$ alle tilfælde miste deres privilegerede stilling.

Dilemmaerne tilspidsedes i begyndelsen af 1950'erne, hvor den mandlige forsørger/kvindelige husmor-familie var både kulturelt og økonomisk dominerende. Dansk Kvindesamfund og ledende socialdemokratiske kvinder opgav i denne periode kampen for særbeskatning af ægtefæller til fordel for en forhøjelse af hustrufradraget. De accepterede, om end nødtvungent, skattelovgivningens favorisering af den dominerende familietype, og at lighed mellem køn måtte vige for lighed mellem klasser. Fra omkring 1960 valgte de igen at argumentere entydigt for særbeskatning - og for en toforsørgerfamilie som norm. Et hovedargument var gifte kvinders økonomiske ligeberettigelse med andre samfundsborgere. Men vigtigere var nok argumentet, at den gxldende lovgivning hindrede gifte kvinders tilgang til arbejdsmarkedet, og at også arbejderklassens kvinder, der mere end andre grupper af kvinder havde erhvervsarbejde, ville vinde ved reformen. Det klare dilemma i forhold til de hjemmearbejdende husmødre og værdsættelsen af deres bidrag til familiens forsørgelse, som afspejles i deres indlæg i debatten, blev ikke løst.
Det gav efterdønninger i form af modsætninger mellem kvinder (Biza et al 1982), tilsyneladende mere i Dansk Kvindesamfund end inden for Socialdemokratiet. ${ }^{10} \mathrm{Og}$ selv om en senere betænkning foreslog en konsekvent gennemførelse af særbeskatningen (Betænkning 1974), var der i Socialdemokratiet og LO i perioden frem til 1982 overvejende stemning for at opretholde et vist økonomisk grundlag for den mandlige forsørger/kvindelige husmor-familie $\mathrm{i}$ form af et dobbelt personfradrag (se LO 1974, 48-49). Og sådan blev det.

Alligevel blev dobbeltindkomst- eller toforsørgerfamilien efterhånden dominerende. Reformen af skattelovgivningen fra 1970 betød et brud i den moderne tanke om manden som familiens forsørger og en tilbagevenden til forestillingen om, at alle voksne skal forsørge sig selv, og at statens ansvar for forsørgelse primært gælder børn. Socialdemokratiets hovedtanke om at velfærdsstatens forsørgelsesproblemer kunne løses inden for familiens rammer uden en reel økonomisk omfordeling til fordel for gifte kvinder viste sig uholdbar (Hansen \& Petersen 2000, 51).

Niels Finn Christiansen og Klaus Petersen kommer således nærmere denne artikels konklusion end Walter Korpi. At hævde, at kønsuligheden mindskedes i Danmark indtil ca. 1975, er næppe holdbart. Derimod giver det mening at sige, at det 'i sidste ende', d.v.s. fra omkring 1970, lykkedes socialdemokraterne at integrere kvinder i det fælles velfærdsstatsprojekt.

Dilemmaet mellem anerkendelse af kvinders arbejde i hjemmet og økonomisk omfordeling mellem køn eksisterer imidlertid fortsat, og forsøgene på at løse det gennem en transformativ politik, der ikke kun giver kvinder de samme rettigheder og muligheder på arbejdsmarkedet som mænd, men destabiliserer kønnet og nedbryder kønsarbejdsdelingen, både i familien og på arbejdsmarkedet, har hidtil været yderst begrænsede, bl.a. fordi danske kvinders og mænds interesser og identiteter, som de 


\section{MÆNDS OG KVINDERS ERHVERVSFREKVENSER 1950-1983}

$\begin{array}{lcccc}\text { Arstal } & \text { Mond } & \text { Kvinder } & \text { Gifte kvinder } & \text { Ugifte kvinder } \\ 1950 & 87,8 & 40,2 & 26,9 & 61,5 \\ 1960 & 83,6 & 33,9 & 22,7 & 51,0 \\ 1970 & 83,2 & 50,8 & 49,2 & 53,7 \\ 1975 & 80,3 & 55,4 & 57,6 & 51,8 \\ 1979 & 79,3 & 60,9 & 65,7 & 53,5 \\ 1983 & 78,4 & 64,7 & 68,5 & \end{array}$

Kilder: Anette Borchorst: Kvinder som arbejdskraftreserve - politisk floskel eller social realitet? Speciale, Aarhus Universitet 1980, bilag 3, s. 202. Anette Borchorst: Krisens konsekvenser for kvindernes stilling pa det danske arbejdsmarked, vurderet i forhold til tesen om, at kvinder fungerer som arbejdskraftreserve. Rapport til Det Samfundsvidenskabelige Forskningsråd, februar 1981, bilag 3, s. 67, med forfatterens senere tilføjelser.

gennem det 20. århundrede, blandt andet takket være skattelovgivningen, er blevet kulturelt konstrueret, ikke harmonerer med en transformativ politik.

\section{NOTER}

1. Tak til Melby et al, kap. 9 (under udgivelse) for denne pointe.

2. Fra $1956 / 57$ erstattedes forsørgerfradraget af en særlig forsørgerskala.

3 . Forsørgerbegrebet anvendtes første gang i tjenestemandsloven af 1919.

4. I forarbejderne til loven blev det eksplicit pointeret, at ægtemænd ikke kunne pålægges husarbejde (se Melby et al, kap. 9, under udgivelse)

5. Det skete på samme tidspunkt i Sverige. Se Florin 1999. For en komparativ analyse af sammenhænge mellem skattelovgivning, familieansvar og beskæftigelse i 12 europæiske lande samt USA og Australien. Se Sainsbury 1999.

6. Et indkomstreguleret børnetilskud til ubemidlede gennemførtes allerede i 1950 (Hansen \& Peter$\operatorname{sen} 2000,38)$.

7. Ella Olsen blev i 1963 valgt til formand for Tobaksarbejderforbundet. Samme år skiftede hun efternavn til Jensen.

8. Siden 1953 havde hustruen haft ret til at læse og underskrive selvangivelsen, men denne ret havde ingen yderligere retlige konsekvenser.

9. Til gengæld skulle børnefradraget/-tilskuddet forhøjes.

10. Ifølge redaktionen af Frie Kvinder havde bla det "notorisk" ikke modtaget indlæg imod Ella Olsens og Jytte Christensens forslag (Frie Kvinder $1963 / 3)$.

\section{LITTERATUR}

- Bergenfeldt, K. (1982) Den ny agtefallebeskatning. FSR's Forlag.

- Betonkning om Beskatningen af Indkomst og Formue m.v. (1948). Afgivet af Skattelovskommissionen, I. Del, J. H. Schultz A/S, Købehavn.

- Betankning om Agtefallers Beskatning (1963) Afgivet af det af finansministeren den 8. marts 1961 nedsatte udvalg. Betænkning nr. 327.

- Betenkning fra Udvalget til Forbedring af Kildeskatten om Agtefollers Beskatning (1974) Betænkning nr. 703.

- Biza, L. Ch., Lange, B. Krebs, Lous, E. K. (1982): "ude eller hjemme". Speciale, Institut for Historie, Aarhus Universitet.

- Blom, I. \& Tranberg, A. (red.) (1985) Nordisk lovoversikt. Viktige lover for kvinner ca. 1810-1980. Nordisk Ministerråd, Oslo.

- CELI \& KAD (2003): Når kønnet taler med - et bidrag til mainstreaming af KAD's overenskomstarbejde, København.

. Christiansen, N. F. \& Petersen, K. (2001) “The Dynamics of Social Solidarity: The Danish Welfare State, 1900-2000", Scandinavian Journal of $\mathrm{H} i$ story, Vol. 26, No. 3.

- Dahlsgaard, I. (1945) “Skat og Ægteskab”, Frie Kvinder 1947/2.

- Dahlsgaard, I. \& Schmidt, E. I. (1945) Skat og Agteskab. Dansk Kvindesamfund/Munksgaard. . Florin, C. (1999) "Skatten som befriar. Hemma- 
fruar mot yrkeskvinnor i 1960-talets särbeskattningsdebatt", in C. Florin, L. Sommestad \& U. Wikander (red.) Kvinnor mot kvinnor. Om systerskapets svairigheter. Norstedts, Stockholm.

- Fraser, N. (1997) "From Redistribution to Recognition? Dilemmas of Justice in a 'Postsocialist' Age", in N. Fraser: Justice interruptus: critical reflections on the "postsocialist" condition. Routledge, New York.

· Frie Kvinder (1963) "Hustruindtægter og samskat”, Frie Kvinder 1963/3.

· Hansen, A. Eklund \& Petersen, K. (2000) "Mellem arbejde og familie. Arbejderbevægelsens familiepolitik 1945-1980", Arbejderhistorie. Tidsskrift for historie, kultur og politik 2000/4.

- Hansen, P. (1963) "En skattereform må også løse sambeskatningsproblemet”, Frie Kvinder 1963/5. · Jensen, E. \& Christensen, J. (1964) “Jeg venter en saglig redegørelse", Frie Kvinder 1964/1.

- Knudsen, L. (2003) Uligestilling $i$ Under-Danmark. Kronik, Information 30. april.

- Korpi, W. (2002) Velferdsstat og socialt medborgerskab. Danmark $i$ et komparativt perspektiv, 1930-1995. Magtudredningen, Institut for Statskundskab, Aarhus Universitet, Århus.

- Ligestillingsrådet (1978) Ligestillingsrådets opleg om skattemessig ligestilling mellem den gifte kvinde og den gifte mand. København.

- LO (1974) Et opleg til debat om skat. LO.

- Lovtidende (diverse år):

Lov om Indkomst- og Formueskat til Staten af 15. Maj 1903.

Lov om Indkomst- og Formueskat til Staten af 8. Juni 1912.

Lov om Indkomst- og Formueskat til Staten af 10. April 1922.

Lov om visse midlertidige bestemmelser vedrørende påligningen af indkomst- og formueskat til staten, 17. december 1952.

Lov om udskrivning af indkomst- og formueskat til staten for skatteåret 1956-57, 28. marts 1956. Lov om opkrævning af indkomst- og formueskat for personer m.v. (Kildeskat), 31. marts 1967. Lov om ændring af lov om opkrævning af indkomst- og formueskat for personer m.v. (Kildeskat), 31. maj 1968.

Lov om ændring af forskellige skattelove (Skattemæssig ligestilling af ægtefæller), 26. maj 1982.

- Melby, K., Pylkkänen, A., Rosenbeck, B., Wetterberg, C. Carlsson (under udgivelse): Agteskabspolitik $i$ Norden. Makadam.

- Olsen, E. (1963) "Hvorfor fortsætte med et forældet forsørgerbegreb?”, Frie Kvinder 1963/4.

- Pedersen, I. M. (1966) Forsørgerbegrebet. Studier i familiens retlige problemer. Betænkning nr. 440 .
- Ravn, A.-B. (2000a) "Gender, Taxation, and Welfare State in Denmark, 1903-63(83)", in K. Melby, A. Pylkkänen, B. Rosenbeck, C. Carlsson Wetterberg (eds.) The Nordic Model of Marriage and the Welfare State. Nord 2000, 27, Nordic Council of Ministers, Copenhagen.

- Ravn, A.-B. (2000b) “Gender, Modernity, and Taxation: Parliamentary Debates on Gender, Class, and Taxation in Denmark, 1945-83", in Restructuring the Welfare State. Conference Report: Workshop 4, GEP International Conference, Vilvorde KursusCenter, August 18-20, 2000.

- Sainsbury, D. (1999) “Taxation, Family Responsibilities, and Employment", in Diane Sainsbury (ed): Gender and Welfare State Regimes. Oxford University Press, Oxford.

- Saunte, E. (1951) "Skattespørgsmålet er stadig aktuelt", Frie Kvinder 1951/3.

- Skattelovskommissionens Betenkning (1950). II.

Del, J. H. Schultz A/S, København.

- Vognbjerg, S. Bache (1963) Betenkning om agtefellers beskatning m.v., LO's arkiv, Kasse 2580, ABA

\section{SUMMARY}

Taking its point of departure in Nancy Fraser's redistribution-recognition dilemma, the article analyses the gendered impact of the Danish tax system 1903-83 and the debates over reform of the system during the formative years of the Danish welfare state, i.e. in the 1950s and 1960s. The author shows how tax laws since the early $20^{\text {th }}$ century contributed to constructing a male breadwinner/female housewife family norm and how the female opponents of the gendered tax system - organized in the Danish Women's Society, the National Council of Women in Denmark, Social Democratic Women's Committees and the Federation of Danish Trade Unions - were caught in a dilemma between socio-economic redistribution in favour of labouring married women on one side and cultural recognition of women's housework on the other.

Anna-Birte Ravn

Lektor i Kønsarbejdsdeling og Samfundsudvikling Institut for Historie, Internationale Studier og Samfundsforhold Aalborg Universitet 